\title{
Prostaglandins for Postpartum Hemorrhage: Pharmacology, Application, and Current Opinion
}

\author{
Yue Chen Wei Jiang Yunchun Zhao Dongli Sun Xiao Zhang \\ Fan $\mathrm{Wu}$ Caihong Zheng
}

Women's Hospital, Medicine of School, Zhejiang University, Hangzhou, China

\author{
Keywords \\ Postpartum hemorrhage · Prostaglandins - Misoprostol · \\ Pharmacology $\cdot$ Side effects
}

\begin{abstract}
Background: Postpartum hemorrhage (PPH) remains a common cause of maternal mortality worldwide. Medical intervention plays an important role in the prevention and treatment of PPH. Prostaglandins (PGs) are currently recommended as second-line uterotonics, which are applied in cases of persistent bleeding despite oxytocin treatment. Summary: PG agents that are constantly used in clinical practice include carboprost, sulprostone, and misoprostol, representing the analogs of $P \mathrm{PF}_{2 a}, \mathrm{PGE}_{2}$, and $\mathrm{PGE}_{1}$, respectively. Injectable PGs, when used to treat PPH, are effective in reducing blood loss but probably induce cardiovascular or respiratory side effects. Misoprostol is characterized by oral administration, low cost, stability in storage, broad availability, and minimal side effects. It remains a treatment option for uterine atony in low-resource settings, but its effectiveness as a uterotonic for independent application may be limited. Key Messages: The present review article discusses the physiological roles of various natural PGs, evaluates the ex-
\end{abstract}

karger@karger.com www.karger.com/pha

Karger $\stackrel{\text { ' }}{5}$

BOPEN ACCESS
(C) 2021 The Author(s)

Published by S. Karger AG, Basel

This is an Open Access article licensed under the Creative Commons Attribution-NonCommercial-4.0 International License (CC BY-NC) (http://www.karger.com/Services/OpenAccessLicense), applicable to the online version of the article only. Usage and distribution for commercial purposes requires written permission. isting evidence of PG analogs in the prevention and treatment of $\mathrm{PPH}$, and finally provides a reference to assist obstetricians in selecting appropriate uterotonics.

(C) 2021 The Author(s)

Published by S. Karger AG, Basel

\section{Introduction}

Postpartum hemorrhage (PPH) is a leading cause of maternal morbidity and mortality. It accounts for approximately $25 \%$ of all deaths of pregnant women worldwide, with an estimated 127,000 deaths per year [1-4]. $\mathrm{PPH}$ has an overall incidence of about $6 \%$ and is associated with serious morbidity. Occasionally, blood transfusions are required with this condition. Moreover, $\mathrm{PPH}$ may lead to renal failure, coagulation deficiencies, anemia, and surgical procedures that can result in loss of fertility. Epidemiologic studies have indicated that the incidence of PPH has been steadily increasing even in many well-resourced countries, for unknown reasons [5]. Between 1994 and 2014, rates of PPH have increased by $26 \%$, and there has been a $50 \%$ rise in $\mathrm{PPH}$ caused by uterine atony $[6,7]$. 


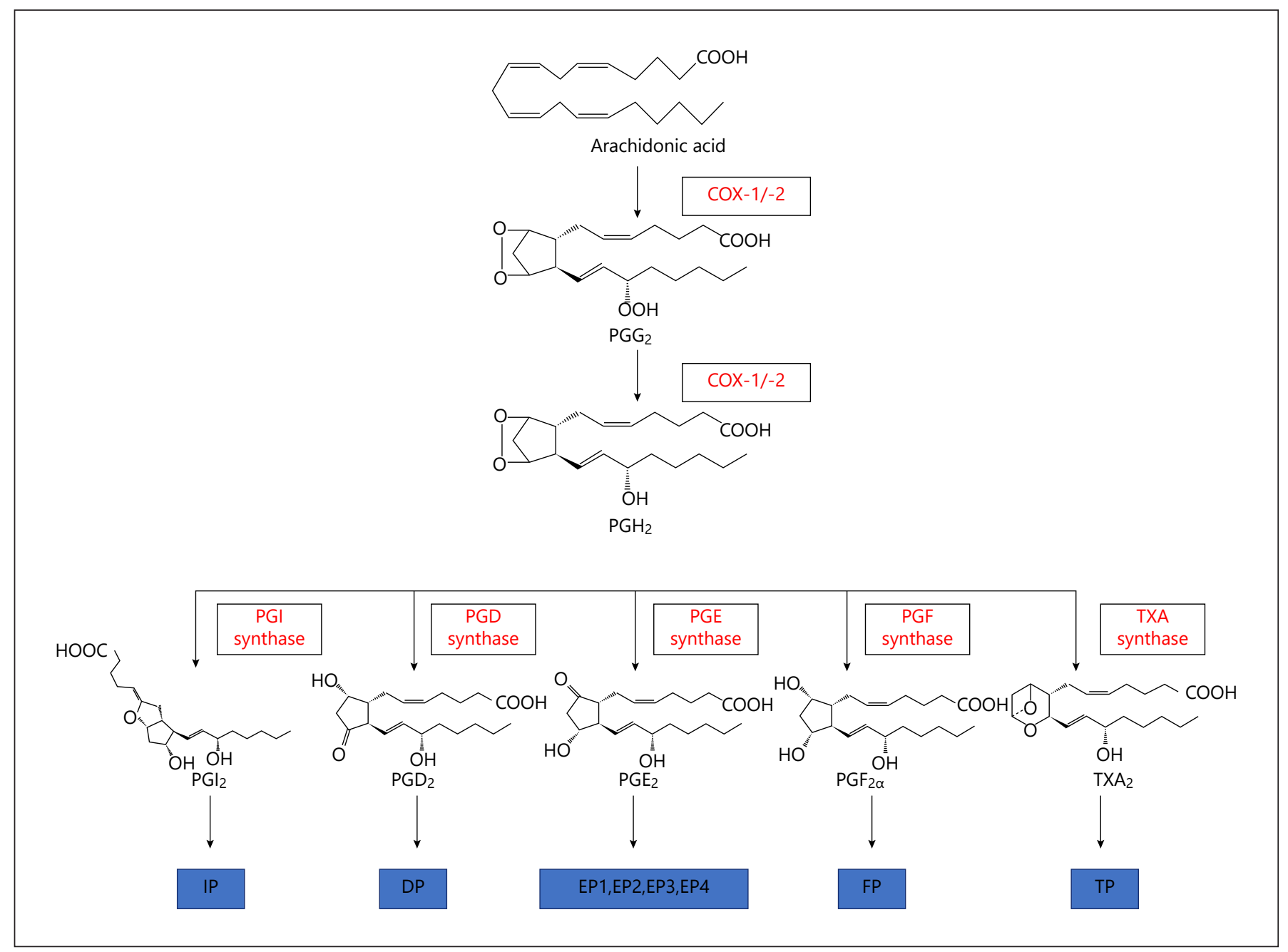

Fig. 1. Metabolism of arachidonic acid. Membrane-bound PG receptors are shown in blue boxes. Cyclooxygenase and related enzymes are shown in red. PG, prostaglandin.

$\mathrm{PPH}$ is usually defined as a blood loss $>500 \mathrm{~mL}$ following a vaginal birth or a loss of $>1,000 \mathrm{~mL}$ after a cesarean birth [8]. The increased rates of atonic PPH have emphasized the importance of active management in the third stage of labor [9]. Data from several large randomized trials have demonstrated that the prevalence rate of $\mathrm{PPH}$ of $>500 \mathrm{~mL}$ was approximately $5 \%$ when active management was applied compared with $13 \%$ when expectant management was used [10]. The evidence appeared to show that active management reduced the average risk of severe primary PPH $(>1,000 \mathrm{~mL})$ at birth. Therefore, it is essential to perform close monitoring, implement additional measures as necessary, and check for the cause of bleeding, especially for women with possible high-risk factors. One such measure is the admin- istration of uterotonics, which is routinely performed postdelivery to prevent excessive postpartum bleeding due to uterine atony [11].

Traditionally, oxytocin has been the treatment of choice for the prevention and treatment of PPH. Compared to no uterotonics $[12,13]$, oxytocin prophylaxis is associated with a reduced risk of $\mathrm{PPH}$, but refractory uterine atony can occur when the uterus fails to adequately contract after oxytocin administration. Owing to the saturation of oxytocin receptors, oxytocin confers the disadvantage of receptor desensitization with repeated injections. In addition, it requires refrigerated conditions for storage and professional personnel for its administration, making it difficult to access in remote, low-resource settings. In the setting of refractory uterine atony, approxi- 
mately $3-25 \%$ of patients require other uterotonics to promote uterine contraction after oxytocin injection [8].

Prostaglandin (PG) agents, as second-line uterotonics, are widely used in contemporary obstetric practice [14]. PGs have strong uterotonic properties, and such agents may be used within obstetrics and gynecology for the purpose of cervical ripening, termination of pregnancy, induction of labor, and $\mathrm{PPH}[15,16]$. In the process of labor, maternal concentrations of endogenous PGs increase gradually in the first stage and steeply in the second stage, and then peak immediately after delivery of the placenta. Noort et al. [17] showed the concentrations of plasma prostaglandin $\mathrm{F}_{2 \alpha}\left(\mathrm{PGF}_{2 \alpha}\right)$ metabolite at placental separation were markedly higher than those at full cervical dilatation, and the concentrations were highest $5 \mathrm{~min}$ after placental separation. Their study showed that one of the possible reasons for uterine atony could be insufficient increase in PG concentration in the third stage of labor. Furthermore, according to the same study, PGs also stimulate the production of oxytocin receptors [18]. Therefore, the application of PGs for the prevention and management of PPH was a logical extension of their critical pharmacological effects in labor. The properties of PGs leading to sustained myometrial contractility are well suited to the management of PPH and its complications.

\section{Pharmacological Role of PGs in the Uterus}

PGs are a series of metabolites formed from arachidonic acid, which are mainly produced by cyclooxygenase (shown in Fig. 1). PGs were originally thought to activate membrane receptors near their formation site. Their different biological activities and generation of second messengers (cyclic AMP [cAMP], inositol phosphates, and $\left.\mathrm{Ca}^{2+}\left[\mathrm{IP} 3 / \mathrm{Ca}^{2+}\right]\right)$ suggested that PGs interact with distinct receptors, and different receptors correspond with different PGs [19]. It was determined that prostaglandin $D_{2}$ $\left(\mathrm{PGD}_{2}\right)$, prostaglandin $\mathrm{E}_{2}\left(\mathrm{PGE}_{2}\right)$, prostaglandin $\mathrm{F}_{2 \alpha}$ $\left(\mathrm{PGF}_{2 \alpha}\right)$, prostacyclin $\mathrm{I}_{2}\left(\mathrm{PGI}_{2}\right)$, and thromboxane $\mathrm{A}_{2}$ $\left(\mathrm{TXA}_{2}\right)$ exert their biological function by interactions with their respective receptors - the DP, EP, FP, IP, and TP receptors [20]. Four subtypes of EP receptor have been identified $\left(\mathrm{EP}_{1}-\mathrm{EP}_{4}\right)$ (Fig. 1). PG receptors are located in the myometrium, trophoblast cells, amnion, and cervix, and all belong to the G-protein-coupled superfamily, incorporating 7 transmembrane domains [21].

The PGs produced in the human endometrium are mainly those of the $\mathrm{E}$ and $\mathrm{F}$ series, while $\mathrm{PGD}_{2}, \mathrm{PGI}_{2}$, and $\mathrm{TXA}_{2}$ occur less frequently [22]. $\mathrm{PGF}_{2 \alpha}$ action is mediated

Prostaglandins for Postpartum

Hemorrhage by the FP receptor, increasing the intracellular calcium concentration $\left(\left[\mathrm{Ca}^{2+}\right]_{\mathrm{i}}\right)$ via the PLC-IP ${ }_{3}-\mathrm{Ca}^{2+}$ pathway. $\mathrm{PGE}_{2}$ acts differently through 4 subtypes $\left(\mathrm{EP}_{1}-\mathrm{EP}_{4}\right)$ in human myometrium: its interaction with $\mathrm{EP}_{1}$ receptors elevates $\left[\mathrm{Ca}^{2+}\right]_{\mathrm{i}}$ via the PLC-IP ${ }_{3}-\mathrm{Ca}^{2+}$ pathway, while $\mathrm{EP}_{2}$ and $\mathrm{EP}_{4}$ receptor signals stimulate the production of adenylyl cyclase. Overall, differences in biological functions of the PG receptors reveal 3 subclusters (shown in Fig. 2). The first of these subclusters consists of receptors TP, FP, and $\mathrm{EP}_{1}$, which increase $\left[\mathrm{Ca}^{2+}\right]_{\mathrm{i}}$ and constitute a group of "contractile" receptors because they cause smooth muscle contraction. The second group consists of receptors IP, $\mathrm{DP}, \mathrm{EP}_{2}$, and $\mathrm{EP}_{4}$, which increase the concentration of intracellular cAMP via Gs protein and are defined as "relaxant" receptors because they induce smooth muscle relaxation. Finally, the third group consists only of $\mathrm{EP}_{3}$ and is generally associated with a decline in cAMP. The "inhibitory" receptor generally causes smooth muscle contraction, depending on the cell type; however, the $\mathrm{EP}_{3}$ receptor can also increase intracellular cAMP and induce $\left[\mathrm{Ca}^{2+}\right]_{\mathrm{i}}[23]$.

\section{PGs in Pregnancy and Birth}

Interestingly, the nonpregnant human uterus contracts in the presence of $\mathrm{PGF}_{2 \alpha}$ and $\mathrm{TXA}_{2}$ but relaxes in the presence of PGE [24]. Uterine strips isolated from pregnant women contract with $\mathrm{PGF}_{2 \alpha}$ and low concentrations of $\mathrm{PGE}_{2}$, while $\mathrm{PGI}_{2}$ and high concentrations of $\mathrm{PGE}_{2}$ induce relaxation [24]. One possible explanation for this is that PG receptor expression varies considerably from the nonpregnant state through pregnancy to birth, and the relative level or type of receptors may dictate the degree of uterine quiescence or contractility [25]. For example, the uterine FP mRNA expression level has been found to decline significantly with gestational age in patients not in labor and then at term increase significantly with labor [26]. Thus, in the initiation of parturition, myometrial active quiescence may change to an active contractile state due to an upregulation of contractile receptors and downregulation of relaxatory receptors [27, 28]. Moreover, the additional control for the onset of labor is built into the increased synthesis of endogenous PGs of the $\mathrm{E}$ and $\mathrm{F}$ series in the uterine compartment [29, 30]. The intra-amniotic, intravenous, or vaginal administration of exogenous PGs can initiate labor at any stage of gestation and in all mammalian species. For pregnant women in labor and placental delivery, PGE or PGF $\mathrm{PF}_{2 \alpha}$ produces a dose-dependent increase in the frequency and 


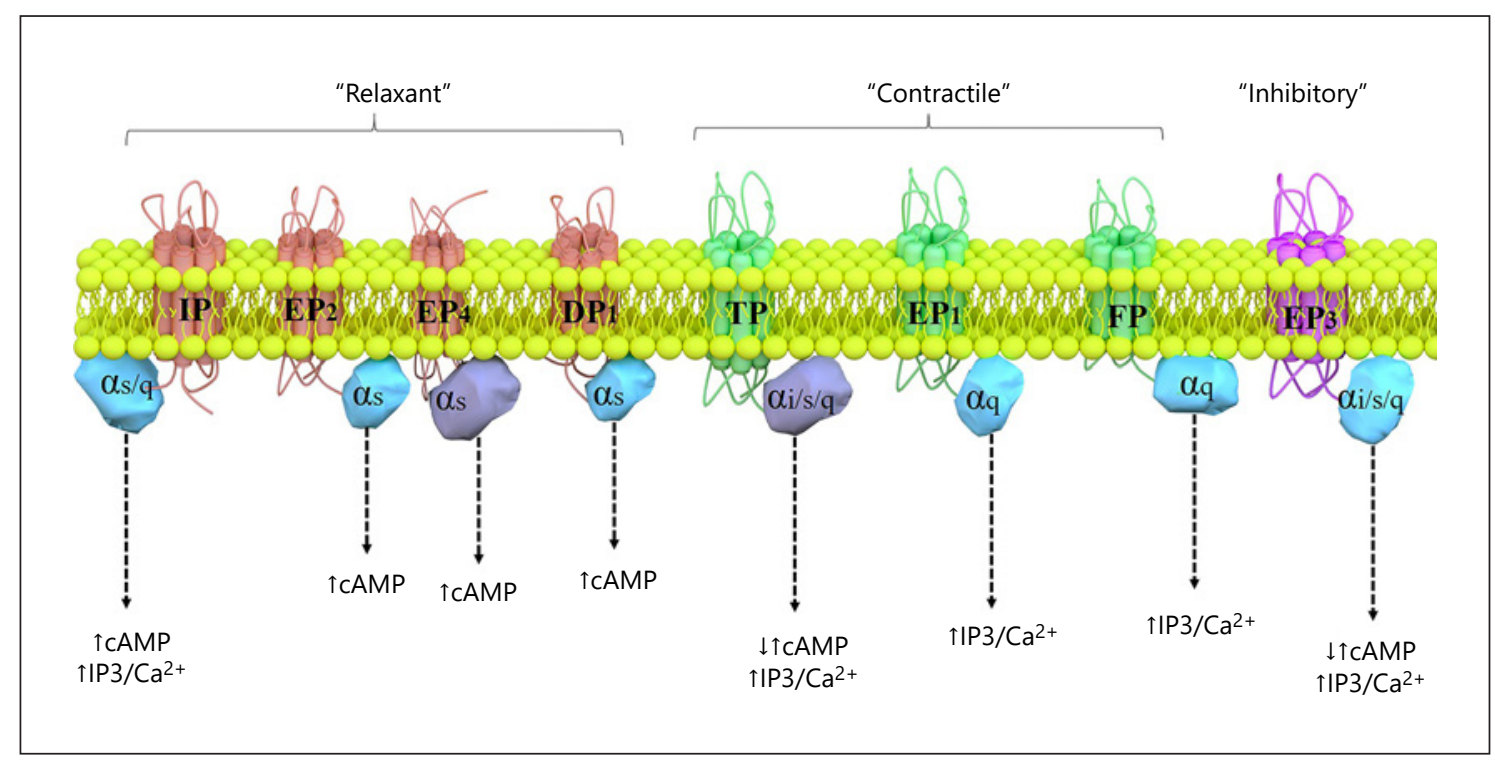

Fig. 2. Prostanoid receptors and their primary signaling pathways. Prostanoid receptors are members of the Gprotein-coupled receptor superfamily. The terms "relaxant," "contractile," and "inhibitory" refer to the phylogenetic characterization of their primary effects.

intensity of uterine contractions [24]. Additionally, $\mathrm{PGE}_{2}$ appears to play a more important role in cervical ripening and rupture of the fetal membranes than in uterine contractility [31].

However, natural PGs may be associated with rapid metabolism, unstable chemical properties, and a number of adverse reactions that limit their clinical applications. Numerous PG analogs have therefore been developed for appropriate clinical use. The preparations are available in the form of injections, tablets, or suppositories based on their intended application. The objective of this review was to evaluate the existing evidence on the roles of various PG analogs in preventing and treating $\mathrm{PPH}$ and to consider their differences in adverse reactions in clinical use.

\section{PG Analogs for PPH}

In the prevention and treatment of $\mathrm{PPH}$, the $\mathrm{PG}$ agents that are frequently used in clinical practice include carboprost, sulprostone, and misoprostol, representing the analogs of $\mathrm{PGF}_{2 \alpha}, \mathrm{PGE}_{2}$, and $\mathrm{PGE}_{1}$, respectively [32].

\section{Side Effects}

Smooth Muscle

Endogenous and synthetic PGs also contract or relax smooth muscles in tissues outside the uterus. In general, $\mathrm{TXA}_{2}, \mathrm{PGF}_{2 \alpha}$, and $\mathrm{PGD}_{2}$ contract, while $\mathrm{PGE}_{2}$ and $\mathrm{PGI}_{2}$ relax the bronchial and tracheal smooth muscles. Numerous case reports have been documented of life-threatening bronchospasm associated with carboprost (a synthetic $\mathrm{PGF}_{2 \alpha}$ analog) [33]. PGEs and PGFs also induce contraction of the main longitudinal muscle in the gastrointestinal tract and increase the movement of water as well as electrolytes into the intestinal lumen. Such physiological effects could explain the watery diarrhea that follows oral or parenteral administration. Generally, diarrhea, cramps, and reflux of bile have been caused by PG agents as well as endogenous PG release such as labor (nausea and hyperthermia), which are common side effects in patients administered PG analogs (including carboprost, sulprostone, and misoprostol) for clinical use.

\section{Cardiovascular System}

Generally, PGs do not directly affect systemic vascular performance. They may, however, modulate local vascular tone at the site of their formation and ultimately affect systemic blood pressure [34]. In most blood vessels, $\mathrm{PGE}_{2}$ elicits vasodilation and a slight drop in blood pressure. $\mathrm{PGF}_{2 \alpha}$ is a potent constrictor of both pulmonary arteries and veins. Blood pressure is increased by $\mathrm{PGF}_{2 \alpha}$ in humans. However, the observed influence of $P G$ analogs on blood pressure is clinically insignificant, although carboprost should be used with caution in hypertensive patients. Direct inotropic effects have been noted with sulprostone (a synthetic $\mathrm{PGE}_{2}$ analog) [35, 36], especially 
when administered directly into the uterine wall. However, there is a contradiction between the role of sulprostone as a coronary artery dilator and the coronary vasospastic hypothesis that causes serious cardiovascular side effects related to sulprostone. Experimental studies [37, 38 ] analyzed the role of endogenous $\mathrm{PGE}_{2}$ in regulating coronary artery resistance and pointed out its vasodilatory effect on arterioles and inhibition of endotheliummyeloid cell interactions; especially in the presence of ischemic factors, it can limit the infarct size. It is considered the treatment with some clinically available PGE analogs, such as misoprostol, could reduce the injury of ischemic cardiomyopathy [38]. Furthermore, we noticed the cases of severe cardiovascular or respiratory side effects reported with the use of injectable PGs to control atonic $\mathrm{PPH}$ were associated with the route of administration that is not recommended, high combined doses of both sulprostone and carboprost, or hemorrhagic shock [39-41]. Therefore, in terms of drug labels and clinical management guidelines [42], direct intramyometrial injections are not approved for sulprostone.

\section{CNS}

The fever caused by a variety of endogenous and exogenous pyrogens is mediated by $\mathrm{PGE}_{2}$ [24]. $\mathrm{PGE}_{2}$ crosses the blood-brain barrier and acts on $\mathrm{EP}_{3}$ or $\mathrm{EP}_{1}$ in thermosensitive neurons. This stimulates the hypothalamus to elevate the body temperature by promoting increased heat production and reduced heat loss. $\mathrm{PGF}_{2 \alpha}$ induces fever but does not participate in the pyretic response. The PG analogs in clinical applications, especially misoprostol, have been shown to be associated with a significantly higher rate of shivering and a body temperature $>38^{\circ} \mathrm{C}$ [43]. A large multicenter study [44] reported an unusually high rate of fever $>40^{\circ} \mathrm{C}(36 \%)$ in Ecuadorian women who received $800 \mu \mathrm{g}$ of misoprostol sublingually compared with other participants $(0-9 \%)$ who received the same regimen. Since the incidence of fever varies greatly in different populations, there is hypothesis that genetic factors may play a role in misoprostol-induced fever [45]. Some studies [46] suggest that genetic variability in ABCC4 and the resultant higher level of misoprostol acid in the brain lead to hyperpyrexia in pregnant women. But after treatments, such effects were related, transient, selflimiting, and do not result in additional health complications [47].

Eye

Prior to the 1970s, studies had demonstrated that the effect of $\mathrm{PGF}_{2 \alpha}$ on the eye was to elevate intraocular pres- sure. Consequently, glaucoma has been a contraindication to the administration of $\mathrm{PGF}_{2 \alpha}$ analogs. Until 1977, studies [48] had confirmed that $\mathrm{PGF}_{2 \alpha}$-induced constriction of the iris sphincter muscle and its overall role on the eyes was to reduce intraocular pressure by increasing the outflow of aqueous humor. This represented a dramatic reversal, in our understanding, of the role of PGs in relation to the eye. Since then, a range of FP receptor agonists have proved effective in the treatment of glaucoma [49]. However, in China, the domestic instructions pertaining to $\mathrm{PGF}_{2 \alpha}$ agents have not been updated in regard to glaucoma as a contraindication. Pharmaceutical companies and national drug administrations have now been informed about the contraindication on the use of $\mathrm{PGF}_{2 a}$ agents in this context.

\section{Injectable PGs}

Injectable PG analogs such as sulprostone and carboprost are generally regarded as second-line uterotonics in $\mathrm{PPH}$ treatment. They induce strong and sustained myometrial contractions and have a reported efficacy of $87-$ $92 \%$ [50]. Injectable PGs are unequivocally considered as suitable medications for $\mathrm{PPH}$ treatment, but not for its prevention. For women at low risk of PPH, injectable PGs are related to more frequent cardiovascular or respiratory side effects [51]. In addition, injectable PGs are currently not available in all medical facilities, and where they are available, the drug cost is high [46]. Therefore, in many clinical management guidelines, injectable PGs are not recommended for the prevention of PPH [52-54]; only if oxytocin or other first-line uterotonics do not provide adequate uterine tone, injectable PGs should be considered. Administration of injectable PGs should be guided by the clinical context and presence of contraindications and follow local hospital policies and availability.

\section{Carboprost}

Carboprost is an analog of $\mathrm{PGF}_{2 \alpha}$. The rapid metabolism of natural PGs limits their clinical application and promotes the development of analogs with longer durations of action. Carboprost tromethamine is a mixture of 15-methyl $\mathrm{PGF}_{2 a}$ and tromethamine (shown in Fig. 3). The oxidation of carboprost, with the hydrogen being replaced by a methyl group, is completely restricted [55]. It has the same pharmacological action as $\mathrm{PGF}_{2 \alpha}$, the contraction intensity of the uterus being 20-100 times stronger than that of $\mathrm{PGF}_{2 \alpha}$. In clinical practice, $80 \%$ of patients with uterine atony exhibited a response below $250 \mu \mathrm{g}$, and $95 \%$ of patients showed a response below $500 \mu \mathrm{g}$ [56]. Dildy's statistics on 1,237 cases of carboprost application 
Fig. 3. Structural formula of $\mathrm{PGF}_{2 \alpha}$ and carboprost. PG, prostaglandin.

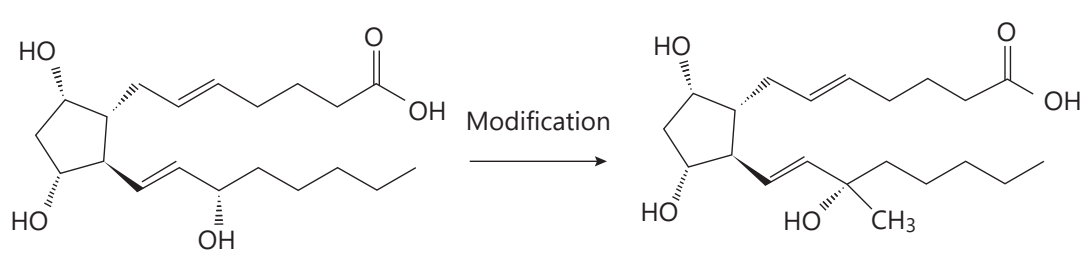

Prostaglandin $\mathrm{F}_{2 \alpha}$ in 12 medical institutions showed that the effective percentage was $94.19 \%$ [57].

In cases of continuous bleeding that is refractory to the administration of oxytocin or ergot alkaloids, injectable PGs are considered the second therapeutic step. Compared to conventional uterotonics, carboprost results in less blood loss and shorter duration of the third stage of labor, but vomiting, abdominal pain, and diarrhea were more common with carboprost administration [15].

Carboprost can, however, cause bronchospasm. Increases in pulmonary and systemic vascular resistance together with intrapulmonary shunting can trigger desaturation of arterial hemoglobin oxygen. Asthma patients are particularly susceptible to these complications, but there are some reported cases of bronchospasm in patients without asthma [58]. It is worth noting that $\mathrm{PGF}_{2 \alpha}$ is an endogenous compound involved both in physiology and in pathology. Many preclinical and clinical studies [59] have revealed $\mathrm{PGF}_{2 \alpha}$ to be associated with severe acute or chronic inflammatory diseases such as rheumatic diseases and is a risk factor for atherosclerosis, diabetes, ischemia-reperfusion, septic shock, and many other conditions. For patients with the above diseases, carboprost should be used with caution, especially when repeated injections are necessary.

\section{Sulprostone}

The Dutch, German, and French guidelines [42, 60, 61] recommend the application of sulprostone, a $\mathrm{PGE}_{2}$ analog, in cases of persistent bleeding despite oxytocin treatment. It is usually administrated by intravenous infusion; intramuscular and intramyometrial injections are contraindicated for sulprostone. A comparative study on the clinical use of sulprostone and carboprost revealed significantly fewer side effects for sulprostone [62]. However, as case reports $[35,36]$ found it to be associated with cardiac arrest in 3 women, manufacturers - with the exception of certain
European countries - later withdrew the drug. While obstetricians may be reluctant to use sulprostone on account of its reported side effects, this issue is controversial because no causal relationship has been documented and the actual frequency of these events remains unknown.

The current French guidelines recommend the use of a continuous intravenous infusion of sulprostone within 30 min after PPH diagnosis if bleeding persists after oxytocin administration, and also that the dose should not exceed $500 \mu \mathrm{g}$ in the first hour and $1,500 \mu \mathrm{g}$ in total. In some population-based studies, with close medication monitoring, sulprostone is thought to be a safe and effective choice for patients with placental retention [63] or for patients with PPH. Severe cardiovascular or respiratory side effects have been found to be uncommon (i.e., a prevalence of $0.1-1 \%$ according to the World Health Organization) [64].

\section{Misoprostol}

Misoprostol, a $\mathrm{PGE}_{1}$ analog registered for the prevention and treatment of peptic ulcer and upper gastrointestinal hemorrhage caused by nonsteroidal anti-inflammatory drugs, has attracted widespread attention because of its strong uterotonic effects and ease of administration. El-Refaey [65] reported the first use of oral misoprostol for the management of the third stage of labor in an observational study. Compared with naturally occurring $\mathrm{PGE}_{1}$, misoprostol exhibits superiority in many aspects. It transforms the chemical structure of natural $\mathrm{PGE}_{1}$ into a more stable form. These modifications (shown in Fig. 4) increase oral activity, duration of action, and safety [66].

Misoprostol is not registered for use during pregnancy, but in most countries, physicians may conduct offlabel drug use with appropriate informed patient consent [67]. The clinical applications of misoprostol in gynecology and obstetrics include medically induced abortion, induction of labor, cervical ripening, and treatment of 
Fig. 4. Structural formula of $\mathrm{PGE}_{1}$ and misoprostol. PG, prostaglandin.

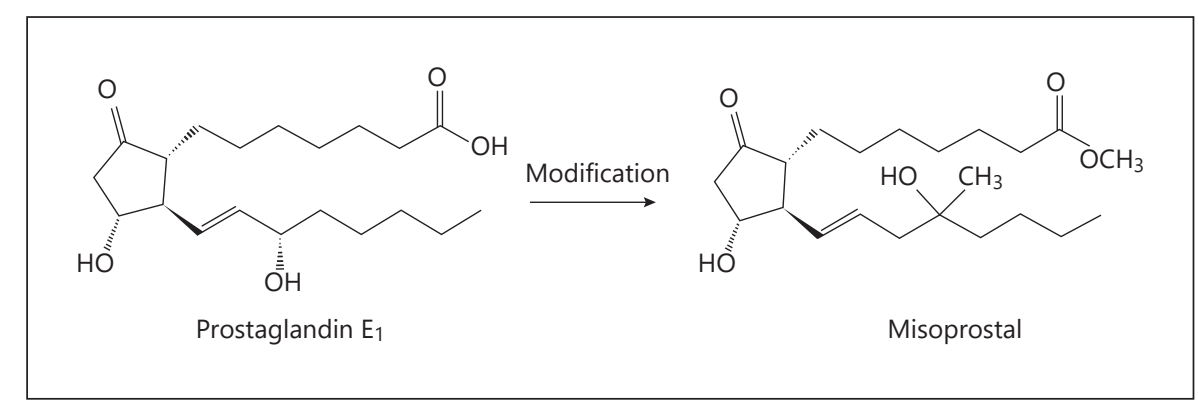

Table 1. Pharmacokinetic parameters of oral, vaginal, sublingual, and rectal misoprostol

\begin{tabular}{|c|c|c|c|c|c|}
\hline & Oral & Vaginal & Sublingual & Rectal & References \\
\hline Time to peak, min & $\begin{array}{l}14.2 \pm 7.0 \\
27.5 \pm 14.8\end{array}$ & $\begin{array}{l}65.0 \pm 21.2 \\
72.0 \pm 34.5\end{array}$ & $26.0 \pm 11.5$ & $71.7 \pm 23.5$ & $\begin{array}{l}{[71]} \\
{[72]}\end{array}$ \\
\hline Peak level, pg/mL & $\begin{array}{l}258.7 \pm 83.8 \\
287.6 \pm 144.3\end{array}$ & $\begin{array}{l}210.8 \pm 63.0 \\
125.2 \pm 53.8\end{array}$ & $574.8 \pm 250.7$ & $86.8 \pm 44.7$ & $\begin{array}{l}{[71]} \\
{[72]}\end{array}$ \\
\hline Area under the curve to $240 \mathrm{~min}, \mathrm{pg} \cdot \mathrm{h} / \mathrm{mL}$ & $\begin{array}{l}151.8 \pm 61.1 \\
369.3 \pm 155.2\end{array}$ & $\begin{array}{l}446.0 \pm 172.1 \\
329.7 \pm 139.0\end{array}$ & $702.1 \pm 274.8$ & $188.9 \pm 126.1$ & $\begin{array}{l}{[71]} \\
{[72]}\end{array}$ \\
\hline
\end{tabular}

Values are expressed as mean $\pm \mathrm{SD}$.

uterine atony. The oral preparation offers stability at room temperature and is significantly cheaper than $\mathrm{PGE}_{2}$ and other analogs. Although misoprostol is administered orally, there are also vaginal, sublingual, buccal, and rectal routes. Rectal administration has been used for the prevention and treatment of PPH [68]. Pharmacokinetic evaluations of misoprostol absorption when administered by various routes have been performed [69-72]. In these studies (shown in Table 1), following an administration dose of $400 \mu \mathrm{g}$, misoprostol demonstrates a routedependent pharmacokinetic profile.

In terms of drug peak time, the oral and sublingual administrations seem to be superior. Sublingual misoprostol achieved the highest peak plasma concentrations $\left(C_{\max }\right)(574 \pm 250.7 \mathrm{pg} / \mathrm{mL})$, and this was significantly higher than those in oral and vaginal routes, which was $287.6 \pm 144.3$ and $125.2 \pm 53.8 \mathrm{pg} / \mathrm{mL}$, respectively. The time to peak concentration $\left(T_{\max }\right)$ was similar in both the sublingual $(26.0 \pm 11.5 \mathrm{~min})$ and oral routes $(27.5 \pm 14.8$ min), which was significantly shorter than those in the vaginal route [72]. Vaginal administrations of misoprostol show a slower pattern and a longer time $\left(T_{\max }=72.0\right.$ $\pm 34.5 \mathrm{~min})$ to peak plasma concentrations $\left(C_{\max }=125.2\right.$ $\pm 53.8 \mathrm{pg} / \mathrm{mL}$ ) [72], but the reduction in plasma concentration is also much slower, with corresponding advan- tages in bioavailability generally. In another pharmacokinetic study of misoprostol [71], the bioavailability of vaginal route as shown by $\mathrm{AUC}_{[240]}$ was $446.0 \pm 172.1$ (pg.h/ $\mathrm{mL}$ ), greater than either oral or rectal misoprostol. In addition, rectally administered misoprostol is similar in terms of its absorption curve to that of vaginal misoprostol, but is lower in bioavailability, which was expressed by $\operatorname{AUC}_{[240]}(188.9 \pm 126.1 \mathrm{pg} \mathrm{h} / \mathrm{mL})$ [71]. The change in plasma concentrations corresponds to the effect on uterine contractility. Taken together, it is considered that the period from the start of treatment to an obvious effect is notably shorter following sublingual and oral administration, and the duration of effect is significantly longer by vaginal and rectal administration. These conclusions will help optimize existing regimens and identify the ideal routes of administration for different clinical indications. In the treatment of $\mathrm{PPH}$, prompt myometrial contractility should be induced by misoprostol, according to pharmacokinetic studies, and oral or sublingual route is preferred with the shortest interval to peak concentrations. In many clinical management guidelines, a single oral/ sublingual/rectal dosage of $600-1,000 \mu \mathrm{g}$ is advocated on $\mathrm{PPH}$ in uterine atony (shown in Table 2). Furthermore, a variety of doses and routes of administration [73-75] have been tested using control regimens that have includ- 
Table 2. Recommendations on the use of misoprostol in the management of PPH

\begin{tabular}{|c|c|c|c|c|}
\hline & Dose and route & $\begin{array}{l}\text { Continuing } \\
\text { dose }\end{array}$ & Precautions/contraindications & Adverse effects \\
\hline ACOG (2017) & $\begin{array}{l}600-1,000 \mu \mathrm{g} \text { sublingual, } \\
\text { oral, or retal }\end{array}$ & n.e. & Rare, hypersensitivity to medication or to PGs & $\begin{array}{l}\text { Nausea, vomiting, diarrhea, } \\
\text { shivering, fever (transient), } \\
\text { and headache }\end{array}$ \\
\hline RCOG (2016) & $800 \mu g$ sublingual & n.e. & Not mentioned & Not mentioned \\
\hline FIGO (2012) & $800 \mu \mathrm{g}$ sublingual & n.e. & Second-line treatment if oxytocin is not available or failed & Risk of pyrexia \\
\hline SOGC (2018) & $\begin{array}{l}400-800 \mu \mathrm{g} \text { oral, sublingual } \\
\text { or } 800-1,000 \mu \mathrm{g} \text { rectal }\end{array}$ & n.e. & Off-label use. Duration of effects is longer for rectal route & $\begin{array}{l}\text { Higher rate of pyrexia for } \\
\text { oral route }\end{array}$ \\
\hline $\begin{array}{l}\text { Queensland } \\
(2020)\end{array}$ & $\begin{array}{l}800-1,000 \mu \mathrm{g} \text { sublingual } \\
\text { or per rectum }\end{array}$ & n.e. & $\begin{array}{l}\text { Use when oxytocin and ergometrine are not successful. } \\
\text { Due to slow onset of action, consider early administration }\end{array}$ & $\begin{array}{l}\text { Increases pyrexia }>38^{\circ} \mathrm{C} \\
>40^{\circ} \mathrm{C} \text { reported in } 1-14 \%\end{array}$ \\
\hline
\end{tabular}

PG, prostaglandin; $\mathrm{PPH}$, postpartum hemorrhage.

ed conventional and nonconventional uterotonics, as well as placebo. It is considered that $400-600 \mu \mathrm{g}$ misoprostol administered orally is optimal for $\mathrm{PPH}$ prevention and $800 \mu \mathrm{g}$ sublingual misoprostol has the most evidence supporting its safety and efficacy for PPH treatment [76, 77]. It is worth noting that rectal administration has also been proposed for application in the third stage of labor. There may be 2 reasons for this application. First, rectal misoprostol likely has a higher degree of bioavailability because the rectal mucosa is moister in the third stage of labor and thus enhances absorption. Second, there are advantages in considering combined dosage regimens that utilize the absorption speed of oral administration, as well as the higher level of bioavailability, and the longer duration of effect, regarding the rectal route in the third stage of labor and postpartum. Vaginal administration may not be practical in active $\mathrm{PPH}$ with massive vaginal bleeding.

As a second-line agent for the prevention and treatment of uterine atony, misoprostol has been suggested as an alternative for the routine management of the third stage of labor. In a meta-analysis [15] of numerous large RCTs comparing misoprostol versus placebo administration, oral or sublingual misoprostol has been shown to be effective in reducing severe PPH and blood transfusion. Compared with conventional injectable uterotonics, oral misoprostol was associated with higher risk of severe $\mathrm{PPH}$, but with a trend toward fewer blood transfusions. Another network meta-analysis [78] comprising 140 randomized trials with data from 88,947 postpartum women indicated the 3 most effective drugs for the prevention of $\mathrm{PPH} \geq 500 \mathrm{~mL}$ were ergometrine plus oxytocin, carbetocin, and misoprostol plus oxytocin combined. It has been suggested that misoprostol, as an adjuvant to oxytocin, can also be applied for earlier interventions when uterine atony is refractory. Overall, when considering areas with poor medical services, the supply and storage of expensive or light-sensitive or temperature-sensitive medications are limited, and misoprostol offers an uterotonic alternative that is inexpensive and easy to store [79]. In 2011, the WHO added misoprostol for the prevention of PPH to the Model List of Essential Medicines, thus solidifying recommendations for its use, including dose and route of administration.

Misoprostol appears to have no serious side effects, in appropriate doses and durations, for the treatment of uterine atony. However, it is associated with higher rates of shivering and fever, along with other PG-related side effects such as nausea, vomiting, and diarrhea. Following misoprostol administration, few women have been shown to have a body temperature $>40^{\circ} \mathrm{C}$ during the first hour after delivery. For every 7-9 women given $600 \mu \mathrm{g}$ of misoprostol, 1 additional woman will have "shivering"; for every 17-21 women, 1 additional woman will have a body temperature $>38^{\circ} \mathrm{C}[43]$. Taken together, the incidence of fever for misoprostol reportedly varies from 10 up to $50 \%$ $[44,80,81]$, which is related to both its dosage and route with the highest incidences found in the high-dose sublingual routes, owing to its pharmacokinetics [82]. However, this is not the only influence on postnatal fever. There appear also to be other effects that could be genetic or cultural $[44,45]$. Clinically, it is worth noting that fever as the side effect of misoprostol and fever caused by postpartum infection need to be distinguished more carefully [83]. There are no contraindications to using misoprostol in postpartum women except in those with a history of an allergic reaction. Asthma is not a contraindica- 
tion as misoprostol is a weak bronchodilator. These tablets do not cause hypertension, which enables them to be used for hypertensive patients.

\section{Conclusion}

Both injectable PGs and misoprostol are preferable as part of the management in the third stage of labor when the first-line treatments for uterine atony have proved ineffective. The choice of which medication to apply should be based on the patients' specific details and the clinical diagnosis of the obstetrician in charge of the case. Therefore, it is important for practitioners to understand both the risks and benefits of commonly used PG agents. Optimizing their use might help mitigate progression to severe $\mathrm{PPH}$ and reduce the need for invasive procedures. As side effects are dose related, optimal effective dose and route of administration during PPH remain an area of active research. We look forward to further advances in preventing and treating $\mathrm{PPH}$ in the future.

\section{Conflict of Interest Statement}

The authors have no conflicts of interest to disclose.

\section{Funding Sources}

This study received funding from Zhejiang Provincial Natural Science Foundation of China (No. LYY21H300006) and the Research funding project of Zhejiang Pharmaceutical Association (No. 2016ZYY06).

\section{Author Contributions}

Y.C. drafted the manuscript. C.H.Z. carried out conceptualization. W.J. assisted in reviewing literature. Y.C. designed and drew the figures in the manuscript. The manuscript was modified by Y.C.Z. and D.L.S. F.W. and X.Z. helped in reviewing the first draft of the manuscript. All authors approved the final manuscript and agreed to be accountable for all aspects of the work.

\section{References}

1 Say L, Chou D, Gemmill A, Tunçalp Ö, Moller $\mathrm{AB}$, Daniels J, et al. Global causes of maternal death: a WHO systematic analysis. Lancet Glob Health. 2014;2(6):e323-33.

2 GBD 2015 Maternal Mortality Collaborators. Global, regional, and national levels of maternal mortality, 1990-2015: a systematic analysis for the Global Burden of Disease Study 2015. Lancet. 2016;388(10053):1775-812.

3 Souza JP, Gülmezoglu AM, Vogel J, Carroli G, Lumbiganon P, Qureshi Z, et al. Moving beyond essential interventions for reduction of maternal mortality (the WHO Multicountry Survey on Maternal and Newborn Health): a cross-sectional study. Lancet. 2013;381(9879): 1747-55.

4 Nathan LM. An overview of obstetric hemorrhage. Semin Perinatol. 2019;43(1):2-4.

5 Kramer MS, Berg C, Abenhaim H, Dahhou M, Rouleau J, Mehrabadi A, et al. Incidence, risk factors, and temporal trends in severe postpartum hemorrhage. Am J Obstet Gynecol. 2013;209(5):449-7.

6 Mehrabadi A, Hutcheon JA, Lee L, Liston RM, Joseph KS. Trends in postpartum hemorrhage from 2000 to 2009: a populationbased study. BMC Pregnancy Childbirth. 2012;12:108.

7 Ford JB, Patterson JA, Seeho SK, Roberts CL. Trends and outcomes of postpartum haemorrhage, 2003-2011. BMC Pregnancy Childbirth. 2015;15:334.
8 Committee on Practice Bulletins-Obstetrics. Practice bulletin No. 183: postpartum hemorrhage. Obstet Gynecol. 2017;130(4):e168-e86.

9 Weeks AD, Fawcus S. Management of the third stage of labour: (for the Optimal Intrapartum Care series edited by Mercedes Bonet, Femi Oladapo and Metin Gülmezoglu). Best Pract Res Clin Obstet Gynaecol. 2020;67:6579.

10 Begley CM, Gyte GM, Devane D, McGuire W, Weeks A, Biesty LM. Active versus expectant management for women in the third stage of labour. Cochrane Database Syst Rev. 2019; 2(2):Cd007412.

11 Parry Smith WR, Papadopoulou A, Thomas E, Tobias A, Price MJ, Meher S, et al. Uterotonic agents for first-line treatment of postpartum haemorrhage: a network meta-analysis. Cochrane Database Syst Rev. 2020;11: Cd012754.

12 Govind N. Prophylactic oxytocin for the third stage of labour to prevent postpartum haemorrhage: a Cochrane review summary. Int J Nurs Stud. 2020:103712.

13 Salati JA, Leathersich SJ, Williams MJ, Cuthbert A, Tolosa JE. Prophylactic oxytocin for the third stage of labour to prevent postpartum haemorrhage. Cochrane Database Syst Rev. 2019;4(4):Cd001808.

14 Butwick AJ, Carvalho B, Blumenfeld YJ, ElSayed YY, Nelson LM, Bateman BT. Secondline uterotonics and the risk of hemorrhagerelated morbidity. Am J Obstet Gynecol. 2015;212(5):642-7.e1.
15 Tunçalp Ö, Hofmeyr GJ, Gülmezoglu AM. Prostaglandins for preventing postpartum haemorrhage. Cochrane Database Syst Rev. 2012;2012(8):Cd000494.

16 Soon JA, Costescu D, Guilbert E. Medications used in evidence-based regimens for medical abortion: an overview. J Obstet Gynaecol Can. 2016;38(7):636-45.

17 Noort WA, van Bulck B, Vereecken A, de Zwart FA, Keirse MJ. Changes in plasma levels of PGF2 alpha and PGI2 metabolites at and after delivery at term. Prostaglandins. 1989; 37(1):3-12.

18 Ravanos K, Dagklis T, Petousis S, MargioulaSiarkou C, Prapas Y, Prapas N. Factors implicated in the initiation of human parturition in term and preterm labor: a review. Gynecol Endocrinol. 2015;31(9):679-83.

19 Kennedy I, Coleman RA, Humphrey PP, Levy GP, Lumley P. Studies on the characterisation of prostanoid receptors: a proposed classification. Prostaglandins. 1982;24(5):667-89.

20 Coleman RA, Smith WL, Narumiya S. International Union of Pharmacology classification of prostanoid receptors: properties, distribution, and structure of the receptors and their subtypes. Pharmacol Rev. 1994;46(2):205-29.

21 Narumiya S, Sugimoto Y, Ushikubi F. Prostanoid receptors: structures, properties, and functions. Physiol Rev. 1999;79(4):1193-226.

22 Jabbour HN, Sales KJ. Prostaglandin receptor signalling and function in human endometrial pathology. Trends Endocrinol Metab. 2004;15(8):398-404. 
23 Tsuboi K, Sugimoto Y, Ichikawa A. Prostanoid receptor subtypes. Prostaglandins Other Lipid Mediat. 2002;68-69:535-56.

24 Brunton L, Chabner B, Goodman L, Knollmann B. Goodman \& Gilman'S The pharmacological basis of therapeutics; 2011.

25 Olson DM, Zaragoza DB, Shallow MC, Cook JL, Mitchell BF, Grigsby P, et al. Myometrial activation and preterm labour: evidence supporting a role for the prostaglandin $\mathrm{F}$ receptor: a review. Placenta. 2003;24(Suppl A): S47-54.

26 Brodt-Eppley J, Myatt L. Prostaglandin receptors in lower segment myometrium during gestation and labor. Obstet Gynecol. 1999; 93(1):89-93.

27 Konopka CK, Glanzner WG, Rigo ML, Rovani MT, Comim FV, Gonçalves PB, et al. Responsivity to PGE2 labor induction involves concomitant differential prostaglandin E receptor gene expression in cervix and myometrium. Genet Mol Res. 2015;14(3):1087787.

28 Unlugedik E, Alfaidy N, Holloway A, Lye S, Bocking A, Challis J, et al. Expression and regulation of prostaglandin receptors in the human placenta and fetal membranes at term and preterm. Reprod Fertil Dev. 2010;22(5): 796-807.

29 Gibb W. The role of prostaglandins in human parturition. Ann Med. 1998;30(3):235-41.

30 Lee SE, Romero R, Park IS, Seong HS, Park $\mathrm{CW}$, Yoon BH. Amniotic fluid prostaglandin concentrations increase before the onset of spontaneous labor at term. J Matern Fetal Neonatal Med. 2008;21(2):89-94.

31 Bakker R, Pierce S, Myers D. The role of prostaglandins E1 and E2, dinoprostone, and misoprostol in cervical ripening and the induction of labor: a mechanistic approach. Arch Gynecol Obstet. 2017;296(2):167-79.

32 Sharma S, El-Refaey H. Prostaglandins in the prevention and management of postpartum haemorrhage. Best Pract Res Clin Obstet Gynaecol. 2003;17(5):811-23.

33 Booker WA, Siddiq Z, Huang Y, Ananth CV, Wright JD, Cleary KL, et al. Use of antihypertensive medications and uterotonics during delivery hospitalizations in women with asthma. Obstet Gynecol. 2018;132(1):185-92.

34 Fitzgerald GA. Chapter 150: prostaglandin mediators. Elsevier Inc.; 2010.

35 Beerendonk CC, Massuger LF, Lucassen AM, Lerou JG, van den Berg PP. [Circulatory arrest following sulprostone administration in postpartum hemorrhage]. Ned Tijdschr Geneeskd. 1998;142(4):195-7.

36 Sorbette F, Delay M, Genestal M, Jorda MF, Carrie D, Montastruc JL, et al. [Cardio-circulatory arrest with mifepristone sulprostone combination for pregnancy interruption]. Therapie. 1991;46(5):387-9.

37 Zhu L, Xu C, Huo X, Hao H, Wan Q, Chen H, et al. The cyclooxygenase-1/mPGES-1/endothelial prostaglandin EP4 receptor pathway constrains myocardial ischemia-reperfusion injury. Nat Commun. 2019;10(1):1888.
38 Zhu L, Zhang Y, Guo Z, Wang M. Cardiovascular biology of prostanoids and drug discovery. Arterioscler Thromb Vasc Biol. 2020; 40(6):1454-63.

39 Hagenaars M, Knape JT, Backus EM. Pulmonary oedema after high infusion rate of sulprostone. Br J Anaesth. 2009;102(2):281-2.

40 Chen FG, Koh KF, Chong YS. Cardiac arrest associated with sulprostone use during caesarean section. Anaesth Intensive Care. 1998; 26(3):298-301.

41 Krumnikl JJ, Böttiger BW, Strittmatter HJ, Motsch J. Complete recovery after $2 \mathrm{~h}$ of cardiopulmonary resuscitation following highdose prostaglandin treatment for atonic uterine haemorrhage. Acta Anaesthesiol Scand. 2002;46(9):1168-70.

42 Bohlmann MK, Rath W. Medical prevention and treatment of postpartum hemorrhage: a comparison of different guidelines. Arch Gynecol Obstet. 2014;289(3):555-67.

43 Gülmezoglu AM, Villar J, Ngoc NT, Piaggio G, Carroli G, Adetoro L, et al. WHO multicentre randomised trial of misoprostol in the management of the third stage of labour. Lancet. 2001;358(9283):689-95

44 Durocher J, Bynum J, León W, Barrera G, Winikoff B. High fever following postpartum administration of sublingual misoprostol. BJOG. 2010;117(7):845-52.

45 Durocher J, Aguirre JD, Dzuba IG, Mirta Morales E, Carroli G, Esquivel J, et al. High fever after sublingual administration of misoprostol for treatment of post-partum haemorrhage: a hospital-based, prospective observational study in Argentina. Trop Med Int Health. 2020;25(6):714-22.

46 Alfirevic A, Durocher J, Elati A, León W, Dickens D, Rädisch S, et al. Misoprostol-induced fever and genetic polymorphisms in drug transporters SLCO1B1 and ABCC4 in women of Latin American and European ancestry. Pharmacogenomics. 2015;16(9):91928.

47 Goldberg AB, Greenberg MB, Darney PD. Misoprostol and pregnancy. N Engl J Med. 2001;344(1):38-47.

48 Camras CB, Bito LZ, Eakins KE. Reduction of intraocular pressure by prostaglandins applied topically to the eyes of conscious rabbits. Invest Ophthalmol Vis Sci. 1977;16(12): 1125-34.

49 Klimko PG, Sharif NA. Discovery, characterization and clinical utility of prostaglandin agonists for the treatment of glaucoma. $\mathrm{Br} \mathrm{J}$ Pharmacol. 2019;176(8):1051-8.

50 Rajan PV, Wing DA. Postpartum hemorrhage: evidence-based medical interventions for prevention and treatment. Clin Obstet Gynecol. 2010;53(1):165-81.

51 Gallos ID, Williams HM, Price MJ, Merriel A, Gee H, Lissauer D, et al. Uterotonic agents for preventing postpartum haemorrhage: a network meta-analysis. Cochrane Database Syst Rev. 2018;4(4):CD011689-CD.
52 WHO recommendations: uterotonics for the prevention of postpartum haemorrhage. World Health Organization. Licence: CC BYNC-SA 30 IGO. 2018.

53 Heesen M, Carvalho B, Carvalho JCA, Duvekot JJ, Dyer RA, Lucas DN, et al. International consensus statement on the use of uterotonic agents during caesarean section. Anaesthesia. 2019;74(10):1305-19.

54 Queensland Clinical Guidelines. Postpartum haemorrhage Guideline No. MN18.1-V9R23. Queensland Health. 2020.

55 Bygdeman M. Pharmacokinetics of prostaglandins. Best Pract Res Clin Obstet Gynaecol. 2003;17(5):707-16.

56 O'Leary AM. Severe bronchospasm and hypotension after 15-methyl prostaglandin $\mathrm{F}$ (2alpha) in atonic post partum haemorrhage. Int J Obstet Anesth. 1994;3(1):42-4.

57 Dildy GA 3rd. Postpartum hemorrhage: new management options. Clin Obstet Gynecol. 2002;45(2):330-44

58 Harber CR, Levy DM, Chidambaram S, Macpherson MB. Life-threatening bronchospasm after intramuscular carboprost for postpartum haemorrhage. BJOG. 2007; 114(3):366-8.

59 Basu S. Bioactive eicosanoids: role of prostaglandin $\mathrm{F}(2 \alpha)$ and $\mathrm{F}_{2}$-isoprostanes in inflammation and oxidative stress related pathology. Mol Cells. 2010;30(5):383-91.

60 Sentilhes L, Vayssière C, Deneux-Tharaux C, Aya AG, Bayoumeu F, Bonnet MP, et al. Postpartum hemorrhage: guidelines for clinical practice from the French College of Gynaecologists and Obstetricians (CNGOF): in collaboration with the French Society of Anesthesiology and Intensive Care (SFAR). Eur J Obstet Gynecol Reprod Biol. 2016;198:12-21.

61 Schmitz T, Tararbit K, Dupont C, Rudigoz RC, Bouvier-Colle MH, Deneux-Tharaux C. Prostaglandin E2 analogue sulprostone for treatment of atonic postpartum hemorrhage. Obstet Gynecol. 2011;118(2 Pt 1):257-65.

62 Biswas A, Roy S. A comparative study of the efficacy and safety of synthetic prostaglandin E2 derivative and 15-methyl prostaglandin F2 alpha in the termination of midtrimester pregnancy. J Indian Med Assoc. 1996;94(8): 292-3.

63 Stefanovic V, Paavonen J, Loukovaara M, Halmesmäki E, Ahonen J, Tikkanen M. Intravenous sulprostone infusion in the treatment of retained placenta. Acta Obstet Gynecol Scand. 2013;92(4):426-32.

64 Masuzawa Y, Kataoka Y, Fujii K, Inoue S. Prophylactic management of postpartum haemorrhage in the third stage of labour: an overview of systematic reviews. Syst Rev. 2018; $7(1): 156$.

65 El-Refaey H, O’Brien P, Morafa W, Walder J, Rodeck C. Misoprostol for third stage of labour. Lancet. 1996;347(9010):1257.

66 Tang OS, Gemzell-Danielsson K, Ho PC. Misoprostol: pharmacokinetic profiles, effects on the uterus and side-effects. Int J Gynaecol Obstet. 2007;99(Suppl 2):S160-7. 
67 Garrigue A, Pierre F. Misoprostol: off-label use in the treatment of post-partum hemorrhage. J Gynecol Obstet Biol Reprod. 2014; 43(2):179-89.

68 Nasr A, Shahin AY, Elsamman AM, Zakherah MS, Shaaban OM. Rectal misoprostol versus intravenous oxytocin for prevention of postpartum hemorrhage. Int J Gynaecol Obstet. 2009;105(3):244-7.

69 Schaff EA, DiCenzo R, Fielding SL. Comparison of misoprostol plasma concentrations following buccal and sublingual administration. Contraception. 2005;71(1):22-5.

70 Meckstroth KR, Whitaker AK, Bertisch S, Goldberg AB, Darney PD. Misoprostol administered by epithelial routes: drug absorption and uterine response. Obstet Gynecol. 2006;108(3 Pt 1):582-90.

71 Khan RU, El-Refaey H, Sharma S, Sooranna D, Stafford M. Oral, rectal, and vaginal pharmacokinetics of misoprostol. Obstet Gynecol. 2004;103(5 Pt 1):866-70.

72 Tang OS, Schweer H, Seyberth HW, Lee SW, Ho PC. Pharmacokinetics of different routes of administration of misoprostol. Hum Reprod. $2002 ; 17(2): 332-6$.
73 Walraven G, Blum J, Dampha Y, Sowe M, Morison L, Winikoff B, et al. Misoprostol in the management of the third stage of labour in the home delivery setting in rural Gambia: a randomised controlled trial. BJOG. 2005; 112(9):1277-83.

74 Soltan MH, El-Gendi E, Imam HH, Fathi O. Different doses of sublingual misoprostol versus methylergometrine for the prevention of atonic postpartum haemorrhage. Int J Health Sci. 2007;1(2):229-36.

75 Chandhiok N, Dhillon BS, Datey S, Mathur A, Saxena NC. Oral misoprostol for prevention of postpartum hemorrhage by paramedical workers in India. Int J Gynaecol Obstet. 2006; 92(2): $170-5$.

76 Sheldon WR, Blum J, Durocher J, Winikoff B. Misoprostol for the prevention and treatment of postpartum hemorrhage. Expert Opin Investig Drugs. 2012;21(2):235-50.

77 Mousa HA, Blum J, Abou El Senoun G Shakur H, Alfirevic Z. Treatment for primary postpartum haemorrhage. Cochrane Database Syst Rev. 2014;2014(2):Cd003249.

78 Gallos ID, Williams HM, Price MJ, Merriel A, Gee H, Lissauer D, et al. Uterotonic agents for preventing postpartum haemorrhage: a network meta-analysis. Cochrane Database Syst Rev. 2018;4(4):Cd011689.
79 Lawrie TA, Rogozińska E, Sobiesuo P, Vogel JP, Ternent L, Oladapo OT. A systematic review of the cost-effectiveness of uterotonic agents for the prevention of postpartum hemorrhage. Int J Gynaecol Obstet. 2019;146(1): 56-64.

80 Pongsatha S, Tongsong T. Outcomes of pregnancy termination by misoprostol at 14-32 weeks of gestation: a 10-year-experience. J Med Assoc Thai. 2011;94(8):897-901.

81 Wong KS, Ngai CS, Yeo EL, Tang LC, Ho PC. A comparison of two regimens of intravaginal misoprostol for termination of second trimester pregnancy: a randomized comparative trial. Hum Reprod. 2000;15(3):709-12.

82 Chong YS, Chua S, Arulkumaran S. Sublingual misoprostol for first trimester termination of pregnancy: safety concerns. Hum Reprod. 2002;17(10):2777, author reply 8 .

83 Nijman TA, Voogdt KG, Teunissen PW, van der Voorn PJ, de Groot CJ, Bakker PC. Association between infection and fever in terminations of pregnancy using misoprostol: a retrospective cohort study. BMC Pregnancy Childbirth. 2017;17(1):7. 